\title{
Understanding the resurgence of traditional authorities in post-apartheid South Africa
}

Article

Accepted Version

Ainslie, A. and Kepe, T. (2016) Understanding the resurgence of traditional authorities in post-apartheid South Africa. Journal of Southern African Studies, 42 (1). pp. 19-33. ISSN 03057070 doi: https://doi.org/10.1080/03057070.2016.1121714 Available at https://centaur.reading.ac.uk/51793/

It is advisable to refer to the publisher's version if you intend to cite from the work. See Guidance on citing.

To link to this article DOI: http://dx.doi.org/10.1080/03057070.2016.1121714

Publisher: Routledge

All outputs in CentAUR are protected by Intellectual Property Rights law, including copyright law. Copyright and IPR is retained by the creators or other copyright holders. Terms and conditions for use of this material are defined in the End User Agreement.

$\underline{\text { www.reading.ac.uk/centaur }}$ 
Central Archive at the University of Reading

Reading's research outputs online 


\title{
Understanding the Resurgence of Traditional Authorities in Post-apartheid South Africa
}

Journal of Southern African Studies, 42 (1): 1-14. (2015)

Andrew Ainslie (University of Reading) and Thembela Kepe (University of Toronto and Rhodes University)

\begin{abstract}
:
Drawing their power not from the ballot box but from a supposedly ancient wellspring of power, hereditary traditional authorities in postcolonial Africa have frequently posed challenges for incoming 'democratic' governments. The situation in post-apartheid South Africa is no different. However contentious their role under the colonial and apartheid systems of government was, the Constitution of the new South Africa (1996) recognised traditional authorities and afforded them opportunities for a political resurgence. This paper reviews the changing status of traditional authorities in the Eastern Cape Province over the twenty years since 1994. It explores the resurgence of the chiefs in relation to the consolidation of both democratic processes and of emergent, neo-patrimonial modes of government. It briefly considers the role of traditional authorities in three key and closely related spheres, namely the institution of the Eastern Cape House of Traditional Leaders, the question of how gender is handled by and within traditional institutions, and the continuing challenges of land administration and development in rural areas. In all these spheres, and in the face of real opposition, the voice and influence traditional authorities have emerged stronger than ever. We conclude by suggesting that as they are drawn deeper into governance and have to play a formal role in addressing the myriad institutional challenges, new questions will and should be asked about the status and influence of traditional authorities, and their substantive contribution to democracy in South Africa.
\end{abstract}

\section{Introduction}

Hereditary traditional authorities ${ }^{1}$ in postcolonial Africa have frequently experienced uncertainties with regard to their institutional and constitutional status in young African democracies. ${ }^{2}$ This is in part because they draw much of their power not from the ballot box,

\footnotetext{
${ }^{1}$ Ntsebeza distinguishes between 'tribal authorities', 'traditional leaders' and 'traditional authorities': L. Ntsebeza, 'Land Rights and Democratization: Rural Tenure Reform in South Africa's Former Bantustans', Transformation, 52 (2003), pp. 68-95. See p. 92, footnote 3. We focus here on chiefs and kings and explicitly exclude headmen from our analysis.

${ }^{2}$ P. Nugent, Africa since Independence (London, Palgrave, 2004); N. Kleist, 'Modern Chiefs: Tradition, Development And Return Among Traditional Authorities In Ghana', African Affairs, 110/441, (2011), pp. 629647; F. B. Nyamnjoh, 'Chieftaincy and the negotiation of might and right in Botswana democracy' in Journal of Contemporary African Studies, 21, 2 (2003), pp. 233-50; H. M. Kyed and L. Buur, 'Introduction: traditional authority and democratization in Africa' in L. Buur and H. M. Kyed (eds.), State Recognition and
} 
but from a different, supposedly more ancient wellspring of signification and power. The post-1994 situation in South Africa is in many respects no different. ${ }^{3}$

The legacy of chiefs in the South Africa is mixed. Although some traditional authorities were instrumental in the struggle against colonialism during the $19^{\text {th }}$ century and against segregation and apartheid during the twentieth century, many traditional authorities were complicit in the elaboration of apartheid policies and legislation in rural, especially Bantustan, areas in the period since the 1950s. ${ }^{4}$ Hendricks and Ntsebeza, two staunch critics of the resurgence of traditional authorities, stuck to first principles when they argued that the chieftaincy was 'inherently undemocratic... [since] chiefs are not elected by popular vote but imposed on the basis of ascription and lineage and [because] there is very little chance of women becoming traditional authorities'. ${ }^{5}$ However, contrary to the popular expectation that after 1994 traditional authorities would atrophy and slowly disappear, their spokespeople have become increasingly assertive and their resurgence over the two decades since 1994 is clearly evident.

We argue that the project to institutionalise democracy in South Africa has taken place on terrain far more complex than a binary opposition between modern urban democrats and traditional rural despots and their respective supporters. ${ }^{6}$ In particular, we argue that the

Democratization in Sub-Saharan Africa: A New Dawn For Traditional Authorities? (New York, Palgrave Macmillan, 2007), pp. 1-28.

${ }^{3}$ L. Ntsebeza, 'Traditional Authorities and Democracy: Are We Back to Apartheid?' in G. Ruiters (ed.), The Fate of the Eastern Cape. History, Politics and Social Policy (Scottsville, University of KwaZulu-Natal Press, 2011).

${ }^{4}$ F. Hendricks, The Pillars of Apartheid: Land Tenure, Rural Planning and the Chieftaincy (Uppsala, Uppsala University, 1990); J. Peires, 'Traditional leaders in purgatory: local government in Tsolo, Qumbu and Port St Johns, 1999-2000,' African Studies 59, 1 (2000), pp. 97-114.

${ }^{5}$ F. Hendricks and L. Ntsebeza, 'The Chieftaincy System is Rooted in Apartheid', Mail \& Guardian, 18 Feb 2000.

${ }^{6}$ M. Mamdani, Citizen and Subject. Contemporary Africa and the Legacy of Late Colonialism (Princeton, Princeton University Press, 1996); T.A. Koelble and E. LiPuma, 'Traditional Leaders and the Culture of Governance in South Africa,' Governance: An International Journal of Policy, Administration, and Institutions 24,1 (2011), pp. 5-29. Richard Sklar goes so far as to argue that '... whether embedded within a constitution or merely exercised informally, traditional rule tends to complement, sustain and legitimate the modern state rather than undermin[e] it. Mixed government implies cooperative interaction among distinct and 
resurgence of traditional authority lies in the opportunities that opened up with the simultaneity of the global neo-liberal economic shifts of the 1990s and the complex reassertion of African identity politics. Identity politics in this context include, among other things, an affirmation of indigenous cultural practice, the assertion of gender equality and strident calls for the return of land to African ownership. But the resurgence should also be situated within the realpolitik of shifting alliances and multi-layered, political-economic interests that have manifested in struggles around development at local, provincial and national levels of the ANC-led government. ${ }^{7}$ Given that this is a review paper, and that these are wide-ranging issues, in the substantive sections that follow we briefly review just three issues that we think help us to understand the resurgence, with particular reference to the Eastern Cape Province. These issues are the uneven institutionalisation of the provincial House of Traditional Leaders, traditional authorities and gender politics, and the vexed questions of land ownership and development. ${ }^{8}$

\section{The challenges and opportunities of the administrative and institutional reconfiguration of the country}

The period 1990-1996 was characterised by the pressing need to deliver a workable political compromise that was based on a negotiated transfer of political power at the national level, with considerable mistrust and political intrigue between the negotiating parties. There

relatively autonomous governmental institutions'. R. Sklar (1994) as quoted in Bank and Southall, 'Traditional Leaders In South Africa's New Democracy', p. 407.

${ }^{7}$ J-F. Bayart, The State in Africa: the Politics of the Belly (London, Polity Press, 1993).

${ }^{8}$ X. Xundu, Foreword in P. Holomisa, According to Tradition. A Cultural Perspective on Current Affairs. $2^{\text {nd }}$ edition (Johannesburg, Real African Publishers, 2012); See J. Beall, S. Mkhize and S. Vawda, 'Emergent Democracy and 'Resurgent' Tradition: Institutions, Chieftaincy and Transition in KwaZulu-Natal', Journal of Southern African Studies, 31,4 (2005) pp. 755-771, see p. 760; L. Ntsebeza, Democracy Compromised: Chiefs and The Politics of Land in South Africa (Leiden, Brill Academic Publishers, 2005). P. Delius, 'Contested terrain: land rights and chiefly power in historical perspective', A. Claassens, and B. Cousins, (eds.), Land, Power and Custom: Controversies generated by South Africa's Communal Land Rights Act (Cape Town, UCT Press, 2008), pp. 211-237. 
followed a period in which the institutions, spheres and processes of governance were either amalgamated, reshaped or established for the first time. In the process, nine new provinces and 834 local government structures were established. Both the provinces and the often economically impoverished local government structures posed serious challenges, but also opportunities, for institutionalising inclusive, democratic governance. ${ }^{9}$

In hindsight, it is possible to see how this fractious and politically fluid period presented nimble-footed political operators, personified by the likes of Advocate Chief Phatekile Holomisa, MP (ANC) and President of the ANC-aligned ${ }^{10}$ Congress of Traditional Leaders of South Africa (Contralesa), and others like Chief Mwelo Nonkonyane, with opportunities that they managed to exploit to the benefit of their organisation and its members. Indeed, these two were among a set of well-educated, articulate and - as Gibbs points out - well-connected individuals who proved adept at turning a period of uncertainty and transition to their political advantage. ${ }^{11}$ They not only imbibed the tenets of the Contralesa Constitution of 1987 which committed the organisation "to unite all traditional leaders and to school them in the politics of liberation, to fight for the eradication of the Bantustan system, to win back the lands 'stolen' from their forefathers during colonialism, and to contribute to the struggle for a unitary, non-racial and democratic South Africa", but they also worked tirelessly to reinsert themselves into both the ANC's national leadership and its regional Xhosa leadership in the Eastern Cape.

\footnotetext{
9 This was in 1995. The number was reduced to 284 in time for the local government elections of 2000, L. Ntsebeza, Democracy Compromised, p67. See T. Lodge. 'Provincial Government and State Authority in South Africa.' Journal of Southern African Studies 31, 4, (2005). pp. 737-753.

${ }^{10}$ SAIRR 1987/88:92, cited in L. Bank and R. Southall, 'Traditional Leaders In South Africa's New Democracy’ Journal of Legal Pluralism 37-38, (1996), pp. 407-430. See p. 415.

${ }^{11}$ T. Gibbs, 'AH! DILINTZABA! "The One Who Breaks Down Barriers": Phatekile Holomisa, a Networked Chief.' Paper presented at the 2011 Critical Studies Seminar Series, the Departments of Politics and International Studies \& Sociology, Rhodes University, 28 Sep 2011.
} 


\section{Three Presidents, three attempts to grasp the nettle that is traditional authority ${ }^{12}$}

When Nelson Mandela became president of South Africa in 1994, after decades of the organisation being banned and its leaders imprisoned or exiled, the ANC was organisationally weak, particularly in rural areas. It was specifically in the provinces in which Bantustan administrations had existed prior to 1994, that chiefs still wielded power, and asserted their ability to 'deliver the rural vote' (such as in KwaZulu-Natal, in the former Transkei and in Limpopo Province), and thus turn the ANC's organisational weakness to their own advantage. ${ }^{13}$

In its early efforts to contain the attempts by the Inkatha Freedom Party (IFP) to foment full-scale civil war in KwaZulu-Natal (KZN), and decisively to wrest rural power in that province away from the IFP's Chief Mangosuthu Buthelezi, the ANC made two concessions to the traditional authorities that Contralesa was quick to capitalise on. ${ }^{14} \mathrm{~A}$ key concession was to recognise and accommodate the Zulu monarch, King Goodwill Zwelithini, within the KZN provincial sphere, while ensuring that his salary and lifestyle were underwritten by the national, ANC-led government. In time, this facilitated a shift in the political allegiance of the Zulu King from the IFP to the ANC and proved instructive for how the ANC might deal with traditional authorities in other provinces. The second concession was a commitment to finding a place for traditional authorities in the vexed sphere of local government and as an identifiable stakeholder in the politically sensitive and administratively

\footnotetext{
12 The short presidency of Kgalema Mothlanthe (25 Sep 2007 to 9 May 2008) is not considered here.

${ }^{13}$ T. Lodge, 'Neo-patrimonial politics in the ANC', in African Affairs, 113 (450), p. 17.

${ }^{14}$ J. Beall et al., 'Emergent Democracy and 'Resurgent' Tradition'.
} 
complex land reform programme. As President Mandela, a traditionalist and an admirer of the chiefs, ${ }^{15}$ increasingly ceded formal power to his deputy, the more technocratic Thabo Mbeki, a more contested political situation began to emerge: national reconciliation and the Reconstruction and Development Programme (RDP) morphed into the neoliberal GEAR (the Growth, Employment and Redistribution) macro-economic programme and a programme of Black Economic Empowerment (BEE) was legislated. Contestation within the ANC-led alliance over economic policy as well as Mbeki's stance on HIV/AIDS and on the situation around land reform in Zimbabwe resulted in serious political tensions within the governing party and alliance. ${ }^{16}$

For traditional authorities, the modernising, rational instincts of Mbeki also caused disquiet: Mbeki shocked the chiefs and their supporters when he set up the Nhlapo Commission ${ }^{17}$ to investigate who among them could be considered legitimate traditional authorities. While Mbeki was said to be ambivalent ${ }^{18}$ about this part of his African heritage, he could not ignore the role of chiefs in drumming up support for the ANC in rural areas. Thus several laws around traditional institutions and land ownership were passed, bolstering the traditional authorities but bewildering both scholars and rural supporters of the ANC. These laws included the Traditional Leadership and Governance Framework (TLGF) Act of 2003, the 2005 Provincial Traditional Leadership Act and the 2008 Traditional Courts Bill. The TLGF had arguably given traditional authorities more powers than they enjoyed under apartheid, as it effectively entrenched the traditional jurisdictions created during the

\footnotetext{
${ }^{15}$ L. Bank and R. Southall, 'Traditional Leaders In South Africa's New Democracy'; T. Gibbs. Mandela's Kinsmen. Nationalist Elites and Apartheid's First Bantustan (Woodbridge, UK, James Currey, 2014).

${ }^{16}$ BBC News, 'Thabo Mbeki's Difficult Presidency', available at http://news.bbc.co.uk/1/hi/world/africa/1296841.stm, retrieved on 30 June 2015.

${ }^{17}$ When the Commission's report was released in 2010, it was widely criticized for, among other things, using questionable methodology for verifying the legitimacy of the traditional authorities under investigation. Eberhard, 'The King, the 'Nhlapo' Commission and the Archive' (2013), available at

http://www.archivalplatform.org/blog/entry/the king the nhlapo_commission_and the archive/,posted on 24 October 2013, retrieved on 30 Dec 2014.

${ }^{18}$ M. Gevisser. Thabo Mbeki. The Dream Deferred. (Jeppestown, Jonathan Ball, 2007). p.13, p.700ff.
} 
formation of the homelands and many rural people who did not recognise these jurisdictions voiced their dissatisfaction. ${ }^{19}$

While political networks at national level and in the provinces began to voice frustration with the direction of economic policy, disquiet in rural areas over dysfunctional local government helped to strengthen the position of traditional authorities. When the 'delivery' of services and employment proved slow, the volatile central region of the ANC in the Transkei, already sympathetic to the ANC's prodigal son, Bantu Holomisa and his United Democratic Movement (UDM), switched allegiances from Mbeki to his arch-rival, Jacob Zuma. ${ }^{20}$ By 2005, Mbeki's assorted enemies, among them committed 'leftists' in the trade union movement, right-leaning populists like Zuma, and others like ANC Youth League leader Julius Malema, were mounting a concerted and deeply divisive campaign to unseat him as ANC president. The ANC national conference at Polokwane in 2007 was to be his ignominious undoing. ${ }^{21}$

Following Mbeki's removal, and under the neo-traditionalist presidency of Jacob Zuma (2009- ), traditional authorities have managed to consolidate key gains made in the early years of their political resurgence. Under Zuma, a national Department of Traditional Affairs was established, and equivalent provincial departments followed. This signalled institutional recognition of a kind that would have been impossible to orchestrate even a decade earlier, when the hostility of 'civics' represented a serious threat to the existence of traditional authorities. Although a National Council of Traditional Leaders had been established in 1997 (and changed in 1998 to the National House of Traditional Leaders), it

\footnotetext{
${ }^{19}$ A. Claassens, 'Denying Ownership and Equal Citizenship: Continuities in the State's Use of Law and 'Custom', 1913-2013' in Journal of Southern African Studies 40, 4, (2014), pp. 761-779; C. Walker. 'Piety in the Sky? Gender Policy and Land Reform in South Africa', Journal of Agrarian Change, 3, 1\&2 (2003), pp.113-148.

${ }^{20}$ G. Ruiters (ed.), The Fate of the Eastern Cape.

${ }^{21}$ H. Marais, South Africa Pushed to the Limit. The Political Economy of Change (Cape Town, UCT Press, 2010).
} 
was now given further endorsement and impetus by the president. Provincial Houses of Traditional Leaders were finally set up in all six provinces where traditional authorities were formally recognised.

Although a far more conciliatory and inclusive approach is generally evident in the relations between government officials and traditional authorities, in July 2010, it was Zuma's unpleasant task to preside over the findings of the Nhlapo Commission, set up by his predecessor. The Commission's report, which was eight years in the making, was met with much dissatisfaction after only seven of the twelve kingships investigated were deemed to be legitimate. The controversies and appeals lodged against the findings of the Nhlapo Commission are partly responsible for a subsequent process set in motion in 2011 by the Zuma administration, namely the Commission on Traditional Leadership Disputes and Claims, the remit of which in settling disputes extends down to the lower levels of traditional authorities (i.e. headmen). ${ }^{22}$

\section{The ANC in government and the possible courses of action for Traditional Authorities}

As noted above, important questions persist about whether a greater role for traditional authorities is constitutionally appropriate, but the question of fiscal sustainability is also relevant. Their contemporary position remains essentially one of perpetual rent-seeking, that is, they need State-provided salaries, medical aid and pensions, and allowances to maintain even modest local administrations.

\footnotetext{
22 N. Tolsi, 'Power and patronage in Pondoland', Mail and Guardian, 29 Jul 2011, available at http://mg.co.za/article/2011-07-29-power-and-patronage-in-pondoland, retrieved 30 December 2014.
} 
Clearly, where central governments prove reluctant to cede to them local powers of taxation, traditional authorities are rendered vulnerable to co-option by government. Indeed, this was the colonial and 'grand apartheid' experience of traditional authorities in South Africa. However, an analysis based solely on who writes their paycheques may be too simplistic: if, as we suggest above, the influence of traditional authorities stems largely from hereditary power, then this in turn ultimately rests to a significant extent - if variable by region - on their control of rural land and thus of the rural people with a stake in that land. As such, their power is independent of political fashion and government paymasters. ${ }^{23}$

It is important to recognise the ambivalence with which the ANC-led alliance has approached the question of traditional authorities. ${ }^{24}$ Van Kessel and Oomen go as far as to say that

the ANC had no clear cut policy on chiefs. Although the institution as such was never officially denounced by the liberation movement, many leading figures in the ANC assumed that chieftaincy would either die of its own accord or otherwise would be abolished. ${ }^{25}$

In the early 1990s, however, and with 'the promise of delivering their 'block vote', chiefs assumed a new importance to the ANC: no longer [were they seen as] relics of a feudal past, but [as] strategic allies in the conquest of state power. ${ }^{26}$ Indeed, in the run-up to the 1994 elections, Nelson Mandela welcomed chiefs into the ANC fold, eager to 'open up a divide

\footnotetext{
${ }^{23}$ L. Ntsebeza, 'Traditional Authorities and Democracy: Are we Back to Apartheid?', in G. Ruiters (ed.)., The Fate of the Eastern Cape (2011).

${ }^{24}$ The ANC's guidelines of 1988 noted that the new constitution [would] ensure that the "institution of hereditary rulers and chiefs shall be transformed to serve the interests of the people as a whole in conformity with ... democratic principles”. L. Bank and R. Southall, 'Traditional Leaders In South Africa's New Democracy', p. 425.

${ }^{25}$ I. Van Kessel and B. Oomen, 'One Chief, One Vote': The Revival of Traditional Authorities in Post-Apartheid South Africa', African Affairs, 96 (1997), pp. 561-585. See p.565.

${ }^{26}$ Ibid. p571: 'In 1990, Contralesa was regarded as an important rural partner in the ANC's strategy to 'isolate De Klerk' by drawing all kinds of disparate forces into a broad alliance under ANC guidance. Chiefs were seen as constituting part of the middle ground between the ANC and the National Party government...'
} 
between the [white] Nationalist government and its conservative African supporters' in a period of unprecedented social change. ${ }^{27}$

The seemingly more innocuous route to steer traditional authorities was as custodians of culture and traditional practices in their specific cultural spheres. This might have been deemed appropriate and sufficient recognition for them in the new democratic dispensation. Here, it was envisaged, they would oversee traditional matters, such as local succession debates, cultural heritage, ritual ceremonies and calendrical events, and the entrenchment of indigenous languages. ${ }^{28}$ But this relatively minor role would not secure the political future of the institutions of traditional authority. Nor did it address wider concerns about the control of land and the rights of women in rural areas. Indeed, the underwhelming performance of traditional authorities in addressing the deaths and injuries during circumcision rituals in the Eastern Cape has caused some to seriously question the role of the institution even in the more limited sphere of cultural practice and heritage. ${ }^{29}$

The option of confining themselves to cultural matters was brushed aside by traditional authorities with the realisation that the near-vacuum in post-1995 rural local government represented a real opportunity for regaining lost ground. ${ }^{30}$ The compromises leading up to the 2000 local government elections provided for highly contested 'wall-towall' local government that often pitted rural and urban civic movements, in the form of South African National Civic Association (Sanco) and ANC councillors, against each other for the limited council positions on offer. As important, the legislation in question provided for ex officio 'observer status' for women, traditional authorities and community

\footnotetext{
${ }^{27}$ L. Bank and R. Southall, 'Traditional Leaders In South Africa's New Democracy', see p. 416. Traditional authorities had an uneasy time of it at the early Codesa negotiations, and Contralesa was excluded (see below). ${ }^{28}$ As Phatekile Holomisa would have it: 'As traditional leaders, [we are] the custodians of African morals, values, cultures and customs...' P. Holomisa, According to Tradition, 2012, p.205.

${ }^{29}$ T. Kepe, 'Secrets' That Kill: Crisis, Custodianship And Responsibility In Ritual Male Circumcision In The Eastern Cape Province, South Africa', Social Science \& Medicine 70 (2010), pp. 729-735.

${ }^{30}$ J. Peires, 'Traditional leaders in purgatory'.
} 
organisations. Whereas a key objection to traditional authorities since 1994 has been their lack of accountability in processes of democratic governance, this concern was overshadowed by high levels of conflict within newly amalgamated rural local municipalities, their accountability and the 'challenges' of service delivery. Overwhelmingly, traditional authorities declined to take up their ex officio positions and chose instead to sit on the sidelines of conflict-ridden local municipal councils whose squabbles animated the regional newspapers and damaged the credibility of local and national government. ${ }^{31}$

Especially telling in this highly contested environment was the inability or unwillingness of the majority of newly elected municipal councillors to engage in meaningful debate and make decisions about land, easily the most significant rural asset, about agricultural development and the provision of rural agricultural infrastructure, mostly because they lacked the technical skills to make informed decisions, but also because they saw rural areas as post-agrarian spaces that required modernisation rather than more agricultural investments. This opened the door for traditional authorities to re-assert themselves, especially among older rural constituencies in this key arena. Thus, the politically weakened traditional authorities found that they could again exert a measure of influence over the day-to-day lives of millions of rural South Africans resident largely in former 'bantustan' areas. ${ }^{32}$ This influence related mostly to obstructing and delaying decisions about where to situate much-needed rural infrastructure such as clinics and schools, fencing, amongst others, and the allocation of temporary but valuable employment opportunities in government-funded public works programmes. $^{33}$

\footnotetext{
${ }^{31}$ L. Ntsebeza, Democracy Compromised, see pp. 66-7.

${ }^{32}$ Kepe notes that traditional authorities have, to all intents and purposes, no authority over their erstwhile 'subjects' who reside in towns and cities in the Eastern Cape. T. Kepe, 'Secrets' That Kill.'

${ }^{33}$ J. Bennett, A. Ainslie and J. Davis, 'Contested Institutions? Traditional Leaders and Land Access and Control in Communal Areas of Eastern Cape Province, South Africa.', Land Use Policy 32 (2013), pp. 27-38.
} 
The situation was exacerbated by the apparent wavering of the ANC: Ntsebeza ${ }^{34}$ notes that it took the ANC government almost ten years to formulate 'laws that reasonably clarify the role of traditional authorities in rural areas.' This was partly down to furious lobbying by chiefs behind the scenes, within government and the ANC itself. Whilst the Bill of Rights of the 1996 Constitution guaranteed the rights of individuals, it did not guarantee group rights, something that - given the apartheid divide-and-rule history of the country - was anathema to the ANC and other progressive forces. While the Constitution itself recognised the existent legally constituted traditional authorities and their continued supervision of indigenous laws and customs, subject to the Bill of Rights ${ }^{35}$, it did not specify the roles, functions and powers of the institution of traditional authorities - it only provided guidelines for legislative processes that would clarify these roles, functions and powers. ${ }^{36}$

As suggested above, because the nascent South African state was built on the institutional ruins of the failed apartheid project of ten 'independent' bantustans and 'selfgoverning' homelands, there existed multiple fissures, contradictions and opportunities for brokers to take up politically useful and expedient roles. After their bitter disappointment at being excluded from a meaningful national role in the negotiations ${ }^{37}$ that led up to elections in April 1994, Contralesa chose to focus much of its organisational efforts at the provincial and local spheres and, indeed, within the ANC itself.

Observers like Ntsebeza and Oomen ${ }^{38}$ have noted that, starting with the national elections in April 1994, the build-up to each successive (national and local) elections saw a flurry of lobbying on the part of traditional authorities, who promised to deliver 'the rural

\footnotetext{
${ }^{34}$ L. Ntsebeza, Democracy Compromised, see p.68.

${ }^{35}$ L. Bank and R. Southall, 'Traditional Leaders In South Africa’s New Democracy', p.409.

${ }^{36}$ L. Ntsebeza. Democracy Compromised, p.65.

37 The ANC apparently thought their presence at the negotiations could play into the hands of their opponents, the National Party negotiators.

${ }^{38}$ L. Ntsebeza, Democracy Compromised; B. Oomen, Chiefs in South Africa: Law, Power and Culture in the Post-Apartheid era (Oxford and New York: James Currey, 2005).
} 
vote' for the ANC in exchange for policy concessions which significantly advanced the cause of the chiefs. Their threat to boycott the November 1995 local government elections saw them squeeze concessions out of the government regarding their demands for more power at provincial and local levels. Davenport and Saunders give a sense of the stridency of their lobbying in noting that

178 traditional leaders and healers met in Parliament in May 1995 to present their case [on the inclusion of powers for traditional authorities in the final constitution]. The delegation included six kings from the Eastern Cape, three paramounts [chiefs], seven princes, sixtyfour chiefs, among them fifteen women. ${ }^{39}$

In reality, quite how central the chiefs have been over the past twenty years in delivering the rural vote, remains a moot point and this no doubt varies considerably from region to region. It seems the ANC prefers not to test this, perhaps on account of its own institutional malaise. Speaking in 2012, the respected political commentator, Somadoda Fikeni, pointed to how internally destabilised the ANC had become, how rife it was with factionalism, nepotism and careerism and how, in the clamour for state patronage, the organisation was in danger of cannibalising itself. ${ }^{40}$ Elected local council structures remain locked in perpetual internal strife over control of budget allocations, the awarding of government tenders and the filling of key administrative positions. Indeed, the image of the (mostly) dignified, articulate king or chief now stands in sharp contrast to the nepotism and unseemly outbreaks of thuggish violence at often shambolic provincial conferences. ${ }^{41}$ This is the arena in which the likes of Phatekile Holomisa, president of Contralesa, ANC MP and, since May 2014, the Deputy

\footnotetext{
${ }^{39}$ R. Davenport and C. Saunders, South Africa: A Modern History (London: Palgrave Macmillan, 2000), pp.578-9.

${ }^{40}$ S. Fikeni, 'Public lecture to the Democracy Development Programme', Durban, 14 August 2012, available at http://www.youtube.com/watch?v=YWW9TXaKEt4, retrieved 20 April, 2014.

${ }^{41}$ M. Pietersen and M. Letsaolo, 'ANC's top six wade into OR Tambo chaos', Mail and Guardian, 15 August 2012, available at http://mg.co.za/article/2012-08-15-ancs-top-brass-orders-continuation-of-or-tamboconference, retrieved 26 December 2014. N. Mkhize, 'ANC Region delays conference again', Business Day Live, 18 Dec 2014, available at http://www.bdlive.co.za/national/politics/2014/12/18/anc-region-delaysconference-again, retrieved 30 December 2014.
} 
Minister of Labour, exhort (especially rural) people to consider what may be lost forever in the headlong rush to adopt all things 'Western'. ${ }^{42}$

The highly symbolic politics of land reform has also offered rich pickings to the traditional authorities. In opposing the government's attempts - signalled by the publication of a White Paper on Land Policy in 1997 - to push forward with the land redistribution programme, traditional authorities asserted the claim of Tribal Authorities to be legal corporations in their own right and claimed that they were therefore not obliged to register with the state. They won plaudits from Africanists (including the Pan Africanist Congress) for rejecting 1913 as the earliest date from which claims for the restoration of land to Africans was to be considered. ${ }^{43}$ The ruling party's response was to fudge the key issues, to court the vocal Contralesa spokesmen, and in the process to add considerably to the frustration of its own Department of Land Affairs officials and of many progressive land and gender activists who had supported the state's land reform programme. ${ }^{44}$ In the sections that follow, we show - with particular reference to the Eastern Cape Province - that the initial caution with which the ANC in government approached traditional authorities has been replaced by zeal. We demonstrate particularly how traditional authorities assert their opinions in day-to-day politics, even where these opinions are in opposition to key democratic principles enshrined in the Constitution. We focus on three short case studies, viz. the activities of the Eastern Cape House of Traditional Leaders, the issue of gender and traditional institutions, and questions of land administration and development in rural areas. We find that a common thread running through these cases is the instrumental nature of the

\footnotetext{
${ }^{42}$ P. Holomisa, According to Tradition.

${ }^{43}$ R. Davenport and C. Saunders, South Africa: A Modern History, p.579.

${ }^{44}$ A. Claassens, 'Who Told Them We Want This Bill? The Traditional Courts Bill And Rural Women', Agenda 23, 82, (2009), pp. 9-22. Walker noted that '[T] he DLA's reluctance to confirm the claims of traditional leaders and tribal authorities to own communal land on behalf of their subjects presented the ANC with awkward political choices, which it was reluctant to address...the ANC's manoeuvrings around the amakhosi have effectively blunted its commitment to gender equity in rural affairs - gender equity is a principle of government more readily endorsed in the urban context.' See C. Walker, 'Piety in the Sky?', p.120.
} 
debates and the limited space allowed for the public, particularly for rural people, to freely articulate their views on the relevant issues.

\section{The Eastern Cape House of Traditional Leaders (ECHTL)}

Despite the setbacks that traditional authorities have faced since 1990, what is clear is that resurgent traditional authorities have become a political force at the national level and by extension, also in the five provinces where they enjoy constitutional recognition. Evidence of this is the establishment in 2010 of the national Department of Co-operative Governance and Traditional Affairs (COGTA), with its own Minister. COGTA has since been renamed the Department for Traditional Affairs (DTA) and had its administrative brief extended. It oversees the relationships between traditional authorities and other government departments and 'spheres' of government, including provincial governments through MINMEC meetings. DTA also holds workshops to address their specific needs for training (including enhancing their knowledge of the Constitution), empowerment and material 'toolsof-the-trade' (i.e. financial rewards). ${ }^{45}$ It aims to support their efforts to transform and reconstitute traditional councils and to provide guidance for the participation of traditional authorities in local government. Significantly, DTA policy documents show this to be a symbiotic relationship, which also underwrites 'building the capacity and the capability of the DTA to support the traditional affairs institutions...in the promotion of good governance and the enhancement of democracy.' 46

\footnotetext{
${ }^{45}$ M. Sibandze, 'Framework For The Provision Of Enabling Resources For A Member Of The National House Of Traditional Leaders, A Member Of Any Provincial House Of Traditional Leaders And Traditional Leaders', Presentation To The Portfolio Committee on Traditional Affairs, [Powerpoint presentation], 10 September 2013, available at https://pmg.org.za/files/130910dta.ppt, retrieved 30 December 2014. See A. Makinana, 'Chiefs Tire of Cheap Frills and Sackcloth,' Mail \&Guardian, 13 June 2013, available at http://mg.co.za/article/2013-09-1300-chiefs-tire-of-cheap-frills-and-sackcloth, retrieved 30 December 2014.

${ }^{46}$ M. Sibandze, 'Framework For The Provision.'
} 
In 2014, evidence indicating the extent of the changed fortunes enjoyed by the traditional authorities in the Eastern Cape included the fact that the Provincial Department of Local Government, Human Settlement and Traditional Affairs had '1,590 posts that support Traditional Affairs and in consequence, the Province [has] reviewed its structure and proposed an elevation from a Chief Directorate to a Branch level (DDG)' ${ }^{47}$ The EC House of Traditional Leaders (ECHTL), under the Chairpersonship of Chief M.J.N. Matanzima, with its nominated and (some) elected 38 members ${ }^{48}$ sits in a new, 'state of the art' building in the provincial capital, Bhisho. The House enjoys the 'best support of any province' in its 'sound relationship and strong partnership' with the EC Provincial Government, demonstrated in an annual budget in excess of R8,7million, including generous 'tools-of-the-trade' packages for its members and for the administration of the House. ${ }^{49}$

Some would argue that this is not all that surprising, since many 'mature' democracies tolerate (costly) constitutional monarchies with inherited privilege of one sort or another. What is surprising, however, given the engagement of the provincial government with the House, is how ill-defined and nebulous in reality the role and work of the ECHTL is. Take the example of just one of the six Committees of the ECHTL, the important Rural Development and Agrarian Reform, Economic Development and Land Affairs (Agriecola) Committee. According to the relevant legislation, this Committee is responsible for (emphasis added):

\footnotetext{
providing support to government departments and other organs of state [in the delivery of] food security and livestock improvement programmes; participating in the land use management programme; promoting protection of the environment and awareness programmes to that effect thereof; supporting promotion of protection of eco-and cultural
}

\footnotetext{
${ }^{47}$ M.C. Nwaila, 'Overview of the Dept of Traditional Affairs', Eastern Cape, 29 October 2013, Department of Traditional Affairs/National House of Traditional Leaders. [Powerpoint presentation]. (2013). Professor Nwaila is the Director-General of the Department of Traditional Affairs.

48 There are six full-time members of the Executive Committee of the ECHTL.

${ }^{49}$ M.C. Nwaila, 'Overview of the Dept of Traditional Affairs'.
} 
tourism; [and] endeavour[ing] to accelerate participation of Traditional Leaders in rural development initiatives by engaging Departments with the same competency. ${ }^{50}$

Simply put, these are all rather broad, vague responsibilities and it is not clear how, when and by whom they will be operationalised. Our attempts to get information on what exactly the ECHTL does were unsuccessful. The limited responses we received from officials in the House led us to conclude that other than commenting on the male circumcision ritual, visiting initiates in the troubled rural areas, as well as fighting for recognition and power within the province, there is as yet no clear role for the ECHTL that justifies the budget allocated to it.

In the next section, we consider the issue of gender politics and the rights of women under customary law in the post-1994 political dispensation.

\section{Traditional authorities and gender politics}

Gender politics have come to characterize some of the key controversies involving the institution of traditional authorities and the issue of gender equality has presented the ANC in government with a dilemma. This is because the Constitutional endorsement of the institution of traditional authorities, and the enshrinement of cultural rights (Sections 30 and 31 of the Constitution) have rendered traditional authorities' patriarchal, and sometimes unconstitutional, views and actions in relation to women, immune to political and legal reprimand. In this section we review a few examples relating to the fraught politics of gender in the Eastern Cape, both to illustrate the apparent brazen disregard of women's constitutional rights by traditional leaders, and how the absence of official reprimand against these patriarchal and sexist views and practices seem to be central to their subsequent political boldness.

\footnotetext{
${ }^{50}$ M.E. Nkantsu, 'Standing rules and orders of the Eastern Cape House of Traditional Leaders'. As amended and adopted by the House on 28 October 2011. (Bhisho, ECHTL, 2011).
} 
There is a clear tension between the principles of gender equality and some cultural rights that are enshrined in the Constitution. ${ }^{51}$ Some cultural practices threaten, and often violate, the rights of women (e.g., land rights) and this violates Section 9(3) of the Constitution, which enshrines equality and non-discrimination based on gender, among other things. ${ }^{52}$ Over the past decade, positions articulated by powerful traditional authorities concerning the role of women within different cultures in the Eastern Cape Province provide an illustration of these tensions and how these play an important role in traditional authorities' campaign to be heard. Some examples that illustrate this are discussed below.

First, in 2013 when Nelson Mandela lay on his deathbed, his family was feuding over who should control the Mandela household after his passing. ${ }^{53}$ On the one hand, there was Mandla Mandela, Nelson Mandela's eldest grandson. Mandla has been acting as the chief of Mvezo area. This was where Nelson Mandela had grown up and was supposed to take over as chief, before he chose to abandon that right and pursue the struggle for the liberation of South Africa. On the other hand, there was Makaziwe Mandela, Nelson Mandela's oldest living (female) child from his first marriage. With both wanting to control the Mandela household, others felt compelled to weigh in, starting with Mandela's second wife Winnie MadikizelaMandela, who argued that Makaziwe, Zenani and Zindzi, Nelson Mandela's only living children, should be allowed to take control of the Mandela family affairs. Winnie earned a sharp rebuke from the AbaThembu royal house, from which Mandela came, arguing that, under the customary rules of primogeniture, Mandla is the only point of entry into Mandela's household. Chief Mfundo Mtirara, the AbaThembu royal house spokesperson, put it more

\footnotetext{
${ }^{51}$ C. Walker, 'Uneasy Relations: Women, gender equality and Tradition.' Thesis Eleven, 115, 1, (2013), pp. $77-$ 94.

${ }^{52}$ A. Claassens, 'Resurgence of tribal levies: double taxation for the rural poor', South Africa Crime Quarterly, 35, (2011). pp. 11-16.

${ }^{53}$ S. Boya and L. Feni, 'Mandla is Mandela Head, say Traditional Experts' Daily Dispatch, 20 December 2013; A. Laing, 'Mandela Family Continues Feud.' Daily Dispatch, 7 January 2014.
} 
bluntly when he said, 'Leadership goes from father to son'. ${ }^{54}$ Xolile Ndevu, Contralesa's general secretary, clarified their position by saying 'Mafungwashe (the first-born daughter) does not lead any traditional ceremonies. There must be a man for that' ${ }^{55}$ Other powerful traditional authority figures, as well as politicians and state officials, were conspicuously silent on this intervention.

Second, over the past few years there has been public controversy regarding the appointment of women as traditional leaders. One of the high profile cases involved NomaXhosa Sigcawu, a princess of the AmaXhosa people. Following the death of her brother, King Xolilizwe Sigcawu, in 2005, the throne passed to her nephew, Prince Mpendulo Sigcawu, and she lodged a case with the Gender Commission on Equality. She argued that she is the rightful heir to the throne of AmaXhosa nation, and that she was passed over for the throne because she is a woman. ${ }^{56}$ Significantly, she received no public support from any traditional authorities.

Finally, there is the case of Nolitha Ludidi, who was appointed as the first female AmaHlubi chief in October 2014. The traditional leader of AmaHlubi people, Langalibalele II Rhadebe, does not recognise Ludidi's leadership role, arguing that 'No woman has ever been appointed permanently as chief' ${ }^{57}$ Sicelo Rhadebe, the traditional leader's spokesperson, tried to explain their opposition to the chieftaincy of Ludidi by saying 'There is no discrimination; it is just custom. In our custom there are specific roles for women and men and there is a reason for that. It would be unfair for the Constitution to abolish our custom' ${ }^{58}$ Ludidi is only the third female chief in the Eastern Cape.

\footnotetext{
${ }^{54}$ S. Boya and L. Feni, 'Mandla is Mandela Head.'

55 Ibid.

${ }^{56}$ L. Feni, 'Not Traditional to have Women Lead', Daily Dispatch, 16 August 2011.

${ }^{57}$ L. Feni, 'Appointment of Female Chief Shunned by Leader', Daily Dispatch, 11 October 2014.

${ }^{58}$ Ibid.
} 
In a controversial move, Chief Phatekile Holomisa, the president of Contralesa, lashed out at women who seek to become traditional leaders, arguing that it was not customary practice. Holomisa defended his position by arguing that: 'this is not unfair discrimination or inequality, but a custom. Traditional leadership is about custom' ${ }^{59} \mathrm{He}$ went on to argue that equality as enshrined in the country's Constitution was not randomly applicable. Holomisa's interpretation of the equality clause in the Constitution is what is puzzling about his position because he is a lawyer and a senior member of government. Nowhere in the Constitution does it state that the equality clause is subject to 'custom'. Rather, the equality principle is above all other rights that are contained in the Bill of Rights (See Section 9 of the Constitution). Again, there was no official censure of these views, which clearly contradicted sections of the Bill of Rights.

The main issue with these examples of deep bias against women on the part of traditional authorities is not that such views exist, but it is the silence on the part of those who are supposed to defend the constitutional rights of all South Africans. It is likely that this silence fosters the impression among the public that traditional authorities have power that matches or even exceeds that of elected politicians. This is because if such views about women were to be promoted by elected politicians, one might expect immediate censure, including calls for their resignation. We argue that this sense of invincibility on the part of traditional authorities is not good for democracy, but it is certainly something that, if not addressed, will undermine the rights of ordinary South Africans. In short, by publicly expressing conservative and sometimes sexist views about gender equality, without being challenged, traditional authorities can only but count their position on gender as another victory in their struggle for recognition. Thus, the price the ANC may be paying for

\footnotetext{
${ }^{59}$ L. Feni, 'Not Traditional to have Women Lead.'
} 
traditional leaders delivering the rural votes is enhanced chiefly control over gender discourse, which may come back to haunt the party in the future.

\section{Traditional authorities, the land and development in rural areas}

In 2004, Chief Phatekile Holomisa wrote:

Our advice to Government is that legal title to communal land [should] be in the name of the relevant traditional authority. Failing to do so would further erode the role of traditional leaders in the life of our people, and would serve to cut the ties among the land, the people and their ancestors who bequeathed the land to us. ${ }^{60}$

He also made the following statement: 'The institution of traditional leadership is inextricably intertwined with the land'. ${ }^{61}$ These two statements by Holomisa aptly capture a central source of the conflict and confusion relating to traditional authorities and the democratic state in South Africa. Traditional authorities believe that the post-apartheid era has effectively stripped them of responsibilities and powers they had in rural areas, particularly their control over land. According to Phago and Netswera, ${ }^{62}$ without controlling land, traditional authorities rightly feel their role in rural development is undermined. Shabangu and Khalo ${ }^{63}$ argue that a source of conflict is that during apartheid, traditional authorities performed similar duties as those prescribed for elected local government representatives as laid out in Sections 152(b) and 153(a) of the Constitution. Even when the government sought to clarify the roles of traditional leaders in Section D 4.1 of the White Paper on Local Government (1998), these were mainly about presiding over traditional courts, village conflicts, and

\footnotetext{
${ }^{60}$ P. Holomisa, 'Securing Rights on Communal Land' in M. Roth, V. Nxasana, S. Sibanda and T. Yates (eds.), Finding Solutions, Securing Rights in South African Land Tenure Reform (Durban: Lexis Nexis Butterworth, 2004), pp. 113-117. See p.115.

${ }^{61}$ P. Holomisa, 'Securing Rights on Communal Land'. See p. 114.

${ }^{62}$ K.G. Phago and F.G. Netswera, 'The Role of traditional leadership in a developmental state: the case of greater Sekhukhune district municipality of South Africa', Journal of Public Administration 46, 3 (2011), pp.1023-1038.

${ }_{63}$ M.H. Shabangu and T. Khalo, 'The Role Of Traditional Leaders In the Improvement Of the Lives Of Communities In South Africa', Journal of Public Administration, 43, (2008), pp. 324-338.
} 
advising government on traditional affairs. The closest these recommendations came to dealing with land and development were suggestions of 'making recommendations on land allocation and settling of land disputes', as well as 'lobbying government and other agencies for development in their areas'. ${ }^{64}$

With regard to land, the role of chiefs in the land stemmed from the entrenchment of communal land rights in the Native Reserves prior to 1948, something that placed chiefs squarely at the centre of land allocation in the reserves. With increasing land shortages, chiefs and headmen became ever more important in land allocation for homesteads and arable production, a phenomenon that Ntsebeza argues still exists today. ${ }^{65} \mathrm{He}$ contends that the continuing role of traditional authorities in land allocation relates to the lack of progress with land reform in rural areas, and the failures of local government in this regard. Given this situation, rural people are simply being pragmatic in turning to traditional authorities in order to access land. Reasserting their de facto role of land allocation in rural areas, traditional authorities view it as one of the bases of their power that constantly reminds both the public and government of their presence in these areas.

Bennett et al. ${ }^{66}$ argue that the Communal Land Rights Act (CLARA) that was passed in 2004 was meant to end the confusion over land administration, by suggesting that land be transferred to 'communities', represented by a land administration committee. It was up to communities to decide whether this committee would be democratically elected or whether an existing 'traditional council' should assume this role. CLARA was heavily criticized for being unconstitutional and for allowing unelected traditional authorities to retain control over local land rights. Following a Constitutional Court challenge, CLARA was withdrawn in

\footnotetext{
${ }^{64}$ Ibid.

${ }^{65}$ W. Beinart (1982) as cited in Bank and Southall, 'Traditional Leaders In South Africa's New Democracy'. L. Ntsebeza, 'Democratic Decentralisation and Traditional Authority: Dilemmas of Land Administration in Rural South Africa.' European Journal of Development Research, 16, 1, (2004), pp. 71-89.

${ }^{66}$ J. Bennett et al., 'Contested Institutions?'.
} 
2010. ${ }^{67}$ However, given that senior traditional authorities hold powerful positions in government, there remains an accommodating platform for them to air their grievances about their role and powers relating to the land in rural areas. ${ }^{68}$

With respect to development in rural areas, how traditional authorities get involved in development in rural areas varies from place to place, depending on a number of issues, including, but not limited to, the political climate in the area. Bank argues that despite the rhetoric of co-operative governance being promoted by the Comprehensive Rural Development Programme unveiled in 2009, there is still a great deal of tension in the Eastern Cape between traditional authorities and elected local government structures around development. ${ }^{69} \mathrm{He}$ argues that there is a widely held belief among government officials that traditional authorities block development projects simply to discredit elected representatives, while municipalities are said to limit development in areas where traditional authorities appear to be vocal and strong.

There are several reasons to suggest that land administration and rural development are both key issues that traditional authorities are using to claw back some of the powers they lost in 1994. First, land tenure reform in South Africa, as exemplified by the withdrawn Communal Rights Act of 2004, is primarily applicable in rural areas, and is essentially about who holds land and how. The failure of the land reform programme to meet its goals in this regard simply makes the status quo with traditional authorities at the helm more real to pragmatic rural dwellers than the delays and uncertainty on the land issue. Second, as Ntsebeza has argued, elected local government in rural areas has been dysfunctional in the arena of development. While their role is still unclear in rural development, their accessibility to the poor rural residents, by virtue of living in these areas, enables traditional authorities to

\footnotetext{
${ }^{67}$ C. Walker, 'Uneasy relations'.

${ }^{68}$ J. Bennett et al., 'Contested Institutions?'

${ }^{69}$ L. Bank, ‘Are Traditional Leaders Stalling Rural Municipal Development?’, Daily Dispatch, 13 May 2011.
} 
facilitate information flow between development agencies and the people. Third, in rural areas, traditional authorities preside over areas occupied by the majority of the poor in South Africa. ${ }^{70}$ This presents them with an opportunity to use the poverty in these areas to draw attention to their own plight, while also arguing that they are the better alternative for facilitating rural development. ${ }^{71}$ Again, as with the case of gender, reluctantly or not, the ANC government appears to be allowing traditional authorities a bigger voice in discourses about rural development and land administration. Ironically, it maybe these very discourses and practices by the chiefs that may gradually turn rural voters away from the ANC.

\section{Conclusions}

It is clear that over twenty years after the political transition of 1994, the role of traditional authorities remains a deeply controversial and divisive work in progress. Traditional authorities have seized the opportunities and resources available to them to fight for recognition and, in the process, have secured a future for themselves as a real force in South Africa's political landscape. ${ }^{72}$

Just how have the traditional authorities managed to this feat? The levers are many, but we have argued that they include the legacy of kinship, cultural and even personal ties of clanship, especially in the case of people like Nelson Mandela (and Jacob Zuma), who had always been sympathetic to the traditional authorities and sought to welcome them into the ANC fold after 1990. Also important is the realisation on the part of political parties that their

\footnotetext{
${ }^{70}$ D. Tessaro and T. Kepe, 'Development' at the crossroads: biodiversity and land use tensions on South Africa's Wild Coast' in International Journal of Sustainable Development and World Ecology, 21(2014), pp. 471-479. See A. Claassens, 'Denying Ownership and Equal Citizenship' for speculation on the attitude of officials and politicians in the ANC government towards traditional authorities in areas where there are valuable mineral resources.

${ }^{71}$ M.H. Shabangu and T. Khalo, 'The Role Of Traditional Leaders In the Improvement Of the Lives Of Communities In South Africa.'

${ }^{72}$ See L. Ntsebeza, 'Democracy compromised', p70.
} 
access to rural voters is intertwined with respecting and acknowledging traditional authorities as 'custodians' of rural areas. ${ }^{73}$ Indeed, the ANC's 'broad church' approach to political mobilisation meant that it sought to incorporate under its umbrella all constituencies that could help it to electorally defeat its political opponents.

As we have argued above, the finely-balanced negotiations and protracted efforts to stave off violent conflict with the IFP in KwaZulu-Natal gave Contralesa valuable early space to manoeuvre within the ANC alliance. ${ }^{74}$ Linked to this, the determined, pragmatic and skilful leadership within Contralesa has enabled traditional authorities to carve out public space for their institution: they appear regularly in the media and the lavish Eastern Cape Provincial House of Traditional Leaders in Bhisho is a testament to their skill, as is the fact that elected politicians (notably provincial premiers and $\mathrm{MECs}^{75}$ ) can be found presenting their annual plans and budgets in this House.

It is a fact that many South Africans derive meaning from their African roots, values and customs, including some elements of culture that traditional authorities claim to embody. These values and customs also form part of the symbolic restoration of the dignity of black South Africans. But the extent to which some of these values clash with accepted, democratic principles of governance has drawn criticism from democrats within the ANC and other political parties who see the values embodied by traditional authorities as an expensive, retrogressive 'ethnic project'.

The fact that traditional authorities have retained effective control over land allocation in significant areas of the Eastern Cape Province, is an important factor in their survival and

\footnotetext{
${ }^{73}$ Statistics South Africa (SSA) went a step further: Their Advertorial Supplement in the Mail and Guardian of 16 September 2011 noted that the Director-General of SSA wished to formally enlist the help of Contralesa 'as part of a critical attempt to manage the undercount [of] the 2001 census' specifically to access 'remote rural communities.' Ever the opportunist, Holomisa opined that 'traditional leaders were best placed to assist' in the enumeration and in identifying 'people in villages who qualified for enumerator employment'. Article available at http://mg.co.za/article/2011-09-16-h3septemberh3h2adding-traditional-leadersh2, retrieved 26 December 2014.

${ }^{74}$ L. Ntsebeza, Democracy Compromised; C.Walker, 'Piety in the Sky?'.

${ }^{75}$ Members of the Executive Council in each province.
} 
resurgence. It is clear that what has occurred is that traditional authorities have been co-opted into state patronage networks (specifically remuneration packages) that will render them both politically more compliant and, as demonstrated above, more publicly assertive.

The success that the chiefs have enjoyed must be set against the ongoing institutional incapacity, infighting and corruption within the local (and provincial) government. These have hampered central government's attempts to deliver basic services to the poor in rural areas, such that central government have yielded to 'transparently sectional interests' for [some of] whom 'tradition is little more than a shield from the demands of democratic accountability'. ${ }^{76}$ The continued weak institutional capacity and low levels of civic mobilisation of the poor in rural areas, and especially of rural women who have arguably most to lose in the drift to a more patriarchal system, have made it more difficult to resist the resurgence of the traditional authorities through popular political action.

But there may be challenges ahead for traditional authorities: for one thing, the Traditional Courts Bill was defeated in February 2014, after it came under sustained attack in the National Council of Provinces, with strong opposition from political actors and civil society in several provinces. ${ }^{77}$ For another, the inability of the traditional authorities in the Eastern Cape to have any positive impact on the circumcision crisis is taken as clear evidence of the limits of their influence. ${ }^{78}$ Finally, the way in which government at national and provincial level has sought (and largely succeeded) to entice traditional authorities into its

\footnotetext{
${ }^{76}$ C. Murray, 'South Africa's Troubled Royalty. Traditional Leaders after Democracy', Law and Policy Paper 23, Centre for International and Public Law (Canberra: Australian National University, 2004), p. 23.

77 'Traditional Courts Bill is dead!', Media Statement by the Alliance for Rural Democracy, Posted on 21 February, 2014, available at http://www.customcontested.co.za/traditional-courts-bill-dead/\#more-895, retrieved12 April, 2014.

78 D.J. Rijken. 'Initiation deaths in the Eastern Cape.' http://ulwaluko.co.za/Problems_files/Statistics.pdf , retrieved 11 October, 2015. According to Rijken, over the last 10 years it is estimated that about 600 young men have died while undergoing the ritual, with many others having to undergo penile amputations. After the first circumcision season of 2015 (June-July), 28 initiates have died. Traditional authorities have consistently lobbied to take control of the ritual, but the deaths have not subsided, particularly due to their poor support of government and biomedical interventions in the ritual.
} 
web of influence and patronage can be expected to affect their standing and their prestige as an independent locus of power in future. The last word goes to Christina Murray:

We must guard against the possibility that a new order revelling in its emancipation from (neo)colonial rule will abrogate its responsibility to its citizens in the name of a new Africanisation. The danger is that settlement with the lobby of traditional leaders will be a smokescreen for the failure to implement democracy where it really matters: at grassroots, in the material conditions of the ordinary existence of women and men. ${ }^{79}$

${ }^{79}$ C. Murray, 'South Africa’s Troubled Royalty', p. 23. 